\title{
ДОСВІД РОЗВИНУТИХ КРАЇН ІЗ ЗАЛУЧЕННЯ ФАРМАЦЕВТІВ І ПРОВІЗОРІВ ДО ПРОФІЛАКТИКИ ТА ЛІКУВАННЯ ЦУКРОВОГО ДІАБЕТУ
}

\author{
Білан О. А., \\ стариий викладач, Кафедра фармацевтичного менеджменту, клінічної фармачії, технології \\ ліків, ПВНЗ «Київський медичний університет», Київ, Украӥна \\ ORCID ID: https://orcid.org/0000-0002-2720-6864 \\ Kyxap O. O., \\ к.фарм.н., дочент, Кафедра фармачевтичного менеджменту, клінічної фармачії, технологї \\ ліків, ПВНЗ «Київський медичний університет», Київ, Украйна \\ ORCID ID: https://orcid.org/0000-0002-2785-4001
}

\begin{abstract}
Новикова Л. Г., стариий викладач, Кафедра фармацевтичного менеджменту, клінічної фармації, технологї ліків, ПВНЗ «Київський медичний університет», Київ, Украйна
\end{abstract}

ORCID ID: https://orcid.org/0000-0001-5103-1016

DOI: https://doi.org/10.31435/rsglobal_ws/31052020/7080

\section{ARTICLE INFO}

Received: 18 March 2020

Accepted: 16 May 2020

Published: 31 May 2020

\section{KEYWORDS}

diabetes,

new roles of clinical pharmacist, management and self-management of diabetes,

prevention of diabetes

complications,

continuing pharmacy professional development.

\begin{abstract}
The prevalence of diabetes mellitus (DM) in the world in general, and in Ukraine in particular, is increasingly showing signs of an epidemic. This chronic disease contributes significantly to increased spending on health care services due to severe complications, loss of capacity to work and increased mortality. Medical specialists see a way out of the crisis as providing patients with the opportunity to manage their disease on their own - in partnership with pharmaceutical specialists, namely, clinical care providers. Traditionally, the role of the pharmacist has been focused on delivering medicines and advising patients on medication, but recently, pharmaceutical professionals have started to become more involved in the management system of type I and type II DM by providing pharmaceutical care $(\mathrm{PhC})$ to patients, thus optimizing treatment, improving clinical outcomes and reducing costs.
\end{abstract}

Citation: Bilan O. A., Kukhar O. O., Novykova L. G. (2020) Experience of Developed Countries in the Attraction of Pharmacists for the Prevention and Treatment of Diabetes. World Science. 5(57), Vol.2. doi: 10.31435/rsglobal_ws/31052020/7080

Copyright: (C) 2020 Bilan O. A., Kukhar O. O., Novykova L. G. This is an open-access article distributed under the terms of the Creative Commons Attribution License (CC BY). The use, distribution or reproduction in other forums is permitted, provided the original author(s) or licensor are credited and that the original publication in this journal is cited, in accordance with accepted academic practice. No use, distribution or reproduction is permitted which does not comply with these terms.

Вступ. Всесвітня організація охорони здоров'я (ВООЗ) у своїх базових документах наголошує на необхідності спрямувати усі галузі медицини на потреби пацієнта. Це вимагає суттєвих змін всієї системі охорони здоров'я, введення ФО, залучення фармацевтичних фахівців до збереження здоров'я населення та зниження захворюваності.

Експерти ВООЗ констатують, що кількість хворих на ЦД І і ІІ типу у світі постійно зростає: у 2015 році діагноз ЦД мали 415 млн. осіб усіх вікових категорій (і ще більше 300 млн. мали переддіабет), а до 2040 року, як передбачається, їх число зросте до 642 мільйонів [3]. До того ж у країнах, що розвиваються, діагностується лише близько третини всіх випадків ЦД, що призводить до зросту кількості серйозних ускладнень (сліпота, ниркова недостатність, інфаркт, інсульт, ампутація нижніх кінцівок і т. ін.), а отже й вартості лікування. Наприклад, за офіційними даними МО3, зараз в Україні налічується більше 1,5 млн. осіб з ЦД, але фахівці 
вважають, що насправді цей показник щонайменше удвічі більший. До того ж і серед пацієнтів, що мають установлений діагноз ЦД, майже $3 / 4$ або не лікуються зовсім, або лікуються неефективно, тобто «не досягають мети лікування» (знизити та підтримувати в нормі рівень глюкози в крові). Серед причин такої ситуації, у першу чергу - відсутність загальнонаціонального скринінгу населення на ЦД та єдиної системи управління лікуванням та способом життя пацієнтів хворих на ЦД, що, в свою чергу, зумовлено браком коштів та нестачею підготовлених фахівців.

Зміни у підходах до лікування та профілактики хронічних хвороб, перехід до європейської Моделі клінічно-фармацевтичного догляду вимагають від медичних i фармацевтичних працівників більшої відповідальності за кінцеві результати у наданні медичної допомоги та забезпеченні якості життя населення. Приміром, сьогодні у США професія «фармацевт» передбачає поглиблену спеціалізацію за 6-ма сертифікованими спеціальностями [5]: «базова фармація» (nuclear pharmacy), «дієтологічне забезпечення» (nutrition support), «фармакотерапія» (pharmacotherapy), «психіатрична фармація» (psychiatric pharmacy), «онкологічна фармація» (oncology pharmacy) i «геріатрія» (geriatrics). Оскільки зараз фармацевтична допомога визначається як «відповідальне надання медикаментозної терапії 3 метою досягнення результатів, що поліпшують якість життя пацієнта» [1], у фармацевтів/провізорів 3’являються нові ролі, в тому числі, у системі менеджменту ЦД.

Мета дослідження. Дослідити досвід розвинутих країн із залучення фармацевтів/провізорів до контролю захворюваності на ЦД, створення нових ролей фармацевтів/провізорів у менеджменті ЦД, організації системи підвищення кваліфікації через поглиблену спеціалізацію в рамках післядипломного навчання.

Методи дослідження. Аналіз літератури (першоджерел); порівняльний аналіз різних методичних підходів до післядипломного навчання фармацевтів/провізорів; контент-аналіз текстів.

\section{Результати дослідження.}

I. Менеджмент ЦД. Лікування хронічних хвороб, таких як ЦД, є складним процесом, до якого в англомовній літературі використовується поняття «управління хворобою» (disease state management, DSM). За даними ВООЗ та Міжнародної діабетичної федерації (International Diabetes Federation, IDF) сьогодні менеджмент ЦД включає наступні фази:

1. Масовий скринінг населення на ЦД. Виявлення пацієнтів з діабетом та ідентифікація пацієнтів з високим ризиком розвитку ЦД, в тому числі шляхом вивчення сімейного анамнезу (наявність випадків діабету І типу, гестаційного діабету і т. ін.).

2. Оцінка стану здоров'я пацієнтів та факторів ризику розвитку ускладнень. Виявлення загрозливих для життя ускладнень, що потребують спеціалізованої медичної допомоги, коморбідних станів, планування вагітності жінками з ЦД і т. ін.

3. Лікування ЦД (замісна та/або коригуюча терапія), попередження, лікування та/або компенсація ускладнень.

4. Реабілітація, соціальна підтримка та мотивація пацієнтів. Навчання пацієнтів та членів їх сімей (самостійний контроль рівня глюкози у крові, дотримання призначень лікаря, регулярна фізична активність, збалансоване харчування, здоровий спосіб життя, прихильність пацієнтів до лікування).

5. Моніторинг стану клінічної та метаболічної компенсації ЦД, контроль виконання пацієнтами призначень лікаря. Вторинна профілактика розвитку ускладнень: плановий скринінг та огляди на ретинопатію, енцефалопатію, гіпертензію, дисліпідемію, діабетичну периферичну нейропатію та ранні ознаки хвороб нирок та печінки.

6. Підтримка зв’язків між пацієнтом й іншими членами команди, що лікує діабет (diabetes care team).

7. Реалізація загальних програм профілактики захворюваності на Цд серед широких верств населення (інформування щодо факторів ризику виникнення ЦД і вибору оптимальної дієти, пропаганда здорового способу життя та відмови від шкідливих звичок, відповідального ставлення до свого здоров'я і т. ін.).

Всі фази інтенсивного менеджменту ЦД можуть бути реалізовані в одному місці (на базі університетської клініки чи спеціалізованого центру лікування ЦД), або децентралізовано, із залученням відділень місцевих лікарень, амбулаторій, аптек, бібліотек і т. ін. Загалом у відношенні до ЦД реалізується система «профілактичної охорони здоров'я» (preventive health care), яка налаштована на: 
- раннє виявлення патології задля полегшення перебігу хвороби та зменшення вірогідності появи ускладнень (на момент встановлення діагнозу ЦД майже половина пацієнтів вже мають ускладнення, пов’язані з цим захворюванням) та

- максимальне залучення пацієнта до самолікування, метою якого є покращення якості життя, поліпшення глікемічного контролю при суворому дотриманні оптимальної маси тіла, рівня ліпідів і артеріального тиску.

Загалом, оптимізація терапії хворих на ЦД - це складна клінічна задача, що потребує скоординованих зусиль великої багатопрофільної команди (multidisciplinary diabetes team, MDT), а також навчання та мотивації пацієнтів.

II. Команди. Дослідження підтверджують, що міждисциплінарний командний підхід до лікування ЦД - більш ефективний спосіб керувати перебігом захворювання та попередження ускладнень. До складу команд можуть входити: клінічний провізор, сімейний лікар, лаборант, медсестра, окуліст, оптометрист, хірург, акушер-гінеколог, ендокринолог, невролог, дієтолог, психіатр, подолог, фізіотерапевт, стоматолог, реабілітолог і т. д. Склад окремих команд може варіювати - в залежності від потреб пацієнтів, наявних умов та ресурсів для лікування (клінічних або амбулаторних), а також наявності профільних спеціалістів, але є й типові состави груп. Наприклад, фахівці Центрів з контролю і профілактиці захворювань (Centers for Disease Control and Prevention) Федерального агентства Міністерства охорони здоров'я США розробили Керівництво з організації командної роботи з профілактики ускладнень ЦД [8]. Вони пропонують створювати PPOD-команди (абревіатура - pharmacy, podiatry, optometry, dentistry), в яких для лікування пацієнтів з ЦД об’єднуються зусилля багатьох медичних і фармацевтичних фахівців, а саме: фармацевта/провізора, подолога, оптометриста та стоматолога.

Члени команди проходять спеціалізовані курси, де навчаються:

а) виявляти ознаки ЦД та системні проблеми у всіх областях PPOD та

б) консультувати своїх пацієнтів щодо особливостей харчування, стилю життя, контролю та профілактики діабету. Кожен із спеціалістів може першим побачити у пацієнта симптоми, пов'язані з ЦД та направити його на скринінг до свого колеги по PPOD команді. Наприклад, подолог може поставити пацієнту такі запитання:

- Чи маєте Ви список усіх ліків, вітамінів та добавок, що приймаєте?

- Чи знаєте Ви для чого Вам призначено кожне з ліків?

- Чи повідомляли Ви про побічні ефекти прийому ліків фармацевта або лікаря?

- Чи розумієте Ви важливість терміну прийому ліків (до, під час або після їжі)?

Якщо пацієнт відповідає на ці питання «ні» або «не впевнений», подолог направляє його до фармацевта/провізора задля консультації та управління медикаментозною терапією.

Пацієнту 3 ЦД, що скаржиться на біль у стопах (або поколювання, підвищену чутливість до дотику, тепла чи холоду, оніміння чи слабкість), фармацевт може розповісти, що діабетична виразка стопи трапляється у 2-7\% хворих на діабет, 9-20\% виразок закінчуються ампутацією, а у 28-83\% хворих протягом 12 місяців з'являються повторні виразки, та порекомендувати негайно звернутися до подолога.

Також, перш ніж звернутися до лікаря первинної медичної допомоги, пацієнт може проконсультуватися з членами PPOD-команди щодо нових симптомів, які вірогідно пов’язані з ЦД.

Отже, фармацевт/провізор у PPOD-команді виконує декілька ролей:

- «консультант з ФО, економічно ефективної терапії»;

- «постачальник послуг первинної медичної допомоги»;

- «радник з питань безпечного та раціонального використання ліків»;

- «провайдер медичної освіти».

III. Нові ролі. Фармацевти/провізори ідеально підходять для участі у програмах «управління хворобою» (DSM), в тому числі ЦД, тому що вони є одними з найдоступніших для населення медичних працівників (health professionals). Дійсно, в аптеку пацієнт може звернутися за консультацією чи порадою без призначення чи попереднього запису, впродовж цілого дня, вечорами та вихідними. Фармацевт/провізор часто бачить свого пацієнта в 7 разів частіше, ніж лікар. Тривалі стосунки з хронічними пацієнтами надають їм доступ до важливої інформації щодо здоров'я людей та створює основу для взаємної довіри та поваги. Це дуже важливо, адже задоволеність пацієнтів взаємовідносинами 3 медичними/фармацевтичними фахівцями $\epsilon$ самостійним фактором лікування, оскільки призводить до позитивних змін у поведінці, що, в свою чергу, веде до поліпшення стану здоров’я, якості життя та більш сприятливого перебігу хвороби. Крім того, фармацевти/провізори постійно контактують із «практично здоровими» людьми, які 
мають ризики розвитку ЦД або переддіабет, а тому потребують «діабетичної освіти» (diabetic education). I нарешті, не останнє місце серед аргументів посідає й той факт, що година роботи фармацевта/провізора коштує дешевше, ніж лікаря вузького профілю.

Звісно, головна роль фармацевта/провізора - консультування з питань медикаментозної терапії діабету (diabetes drug adviser/consultant) на всіх етапах лікування захворювання, що передбачає надання пацієнтові інформації стосовно дії ліків, способів їх застосування, зберігання, змін у ліцензуванні, постачанні та доступності ліків, тривалості лікування, можливості поєднання призначених ліків 3 іншими ліками та їжею, раціонального використання ліків та зменшення поліпрагмазії, побічних ефектів та ускладнень. Але якщо додати до консультування нефармакологічні заходи, надання інформації про гострі та хронічні ускладнення і т. ін., то фармацевти /провізори зможуть надавати населенню ще й первинну медичну допомогу при діабеті (primary care diabetes). Навіть на базі звичайного аптечного закладу вони в змозі надати наступні послуги:

- навчання та підтримка самоконтролю рівня глюкози у крові (self-monitoring of blood glucose, SMBG), консультації щодо ситуацій, коли рівень глюкози виходить за межі допустимого діапазону, включаючи розробку плану дій на випадок, якщо рівень цукру стає занадто високим чи низьким;

- моніторинг артеріального тиску, ваги та рівня ліпідів у крові;

- контроль виконання пацієнтами призначень лікаря та їх прихильності до медикаментозної терапії;

- нагадування пацієнтам про важливість регулярних обстежень очей, судин, ніг і т. ін. на наявність ускладнень, пов'язаних $з$ діабетом;

- визначення проблем, пов'язаних з прийомом ліків (сумісність, побічні дії);

- забезпечення первинної діабетичної освіти, в тому числі членів родин пацієнтів (особливо важливо це для батьків дітей);

- мотивація до модифікації способу життя, дотримування індивідуального плану харчування, регулярних фізичних навантажень, відмови від шкідливих звичок;

- допомога у вирішенні емоційних проблем, що супроводжує життя із хронічним захворюванням.

В умовах стаціонару клінічний фармацевт/провізор коригує та оптимізує медикаментозну терапію, призначену профільними спеціалістами, веде моніторинг іiі виконання (комплайенс) та оцінює ефективність запропонованих схем лікування. В деяких країнах фармацевти/провізори мають настільки високий авторитет, що там реалізується практика «сумісного керування медикаментозною терапією» (collaborative drug therapy management, CDTM). Суть її полягає в тому, що після проходження практики (в діагностичному або лікувальному центрі, чи в амбулаторії на базі лікарні) кваліфіковані фармацевти/провізори на основі спеціального протоколу (pharmacist-led collaborative drug therapy management protocol) можуть керувати складними схемами прийому ліків для конкретного захворювання, коригувати їх або навіть припиняти призначення. Такий підхід покращує результати лікування, поліпшує дотримання пацієнтами режиму прийому ліків та знижує ризик їх побічних дій, а також зменшує витрати на охорону здоров'я. У США національна програма медичного страхування для осіб віком від 65 років и старше (Medicare) навіть надає літнім людям з ЦД можливості відшкодування витрат на послуги 3 боку фармацевта/провізора 3 управління медикаментозною терапією.

IV. Педагог 3 діабету. Оскільки в загальній системі менеджменту ЦД велике значення приділяється первинній профілактиці захворюваності й профілактиці розвитку ускладнень, в командах з'являється іще одна нова роль - «педагог 3 діабету» (diabetes educator). Цей спеціаліст навчає та мотивує 1) пацієнтів 3 діабетом і членів їх сімей, 2) представників груп ризику на виникнення ЦД та 3) населення в цілому. Роль педагога з діабету можуть виконувати різні професіонали галузі охорони здоров'я: лікарі сімейної практики, медсестри, дієтологи, фізіотерапевти, психіатри, неврологи і т. д., які пройшли спеціальну підготовку для роботи 3 хворими на ЦД. Але найчастіше до команд педагогів 3 діабету (diabetes education team) залучаються саме фармацевти/провізори.

Фармацевти/провізори ведуть Школи діабетиків, курси самоменджменту діабету для пацієнтів з ЦД і т. п. - як в амбулаторіях, так і в умовах стаціонару. Навчання самоконтролю при лікуванні ЦД (diabetes self-management education, DSME) допомагає пацієнтові отримати знання, навички та поведінкові паттерни, що необхідні для самостійного догляду [4]. Лікарі та 
фармацевти, зі свого боку, надають пацієнтові підтримку у формуванні навичок і реалізації поведінки, необхідних для самостійного «керування» хворобою на постійній основі. Задля більш широкого охоплення населення діабетичною освітою вони використовують:

- сучасні технології, такі як телемедицина (telehealth) [7], дистанційна освіта (e-learning, webinars) і т. ін.;

- групове навчання, наприклад, у «Школах діабету» та на так званих «спільних лікарських прийомах» (shared medical appointments), куди запрошується група пацієнтів із схожими захворюваннями чи проблемами для подальшої допомоги та лікування хронічних станів.

У США «педагог $з$ діабету» вже добре інституціолізована професія, тут діє Асоціація фахівців з питань діабетичної допомоги та освіти (Association of Diabetes Care and Education Specialists, ADES), яка об'єднує понад 15 тис. сертифікованих diabetes educators. На кожного 3 цих фахівців припадає близько 1,6 тис. пацієнтів, що потребують їх послуг.

До діабетичної освіти населення долучаються також наукові та навчальні медичні установи, котрі розробляють різноманітні методичні матеріали для фармацевтів та пацієнтів. Наприклад, Національний інститут діабету, захворювань травлення та нирок США (The National Institute of Diabetes and Digestive and Kidney Diseases) пропонує дистанційні освітні програми з самолікування для хворих на ЦД (diabetes self-management education programs), які допомагають людям навчитися дбати про себе якнайкраще.

V. Навчання. Для успішного виконання нових ролей у лікуванні ЦД («фармацевт у системі менеджменту діабету», «педагог 3 діабету») фармацевту/провізору необхідні додаткові знання i уміння, а також розвинуті навички спілкування. Отримати їх можна, пройшовши додаткове навчання та спеціалізацію. Приміром, процес сертифікації «педагога з діабету» передбачає:

1) навчання на спеціалізованих курсах лікування діабету (diabetes management courses) або у «Школах діабету» (Schools of diabetes);

2) накопичення практичного досвіду роботи з цільовими групами пацієнтів (не менше 1 тис. годин);

3) виконання екзаменаційних завдань (практичних і ситуаційних).

Наприклад, до програми «Школи діабету» IDF для педагогів з діабету, включені такі теми: «Переддіабет та діагностика діабету»; «Роль педагога 3 діабету»; «Діабет та зміни способу життя»; «Терапія інсуліном. Введення інсуліну»; «Психологічні та соціальні проблеми при діабеті»; «Діабет та захворювання порожнини рота»; «Діабет та сексуальне здоров'я»; «Діабет в особливих групах населення - діти, вагітні жінки та люди похилого віку»; «Самостійне управління діабетом (diabetes self-management)». Окрім того, щоб налагодити взаємодію на рівні «рівноправного терапевтичного партнерства» лікарям та фармацевтам пропонується пройти спеціалізовані «Онлайн курси діабету», акредитовані Європейською акредитаційною радою з безперервної медичної освіти (European Accreditation Council for Continuing Medical Education, EACCME), такі як «Попередження діабету II типу», «Діабет та кардіоваскулярні хвороби» і т. ін. [9].

Навчальні курси та сертифікаційні програми в рамках подальшої професійної освіти пропонують медичні коледжі та університети, медичні та фармацевтичні школи, професійні асоціації, державні та недержавні установи. Наприклад:

- Американська асоціація фармацевтів (The American Pharmacists Association, APhA) пропонує «Сертифікаційну тренінгову програму лікування діабету з фокусом на пацієнта», яка базується на сучасних концепціях лікування ЦД та стандартах ФО. Головні цілі програми інтегрувати теоретичні знання щодо патофізіології діабету у практику ФО через опрацювання кейсів та вдосконалення навичок. Програма складається 36 модулів: 1. «Патогенез і діагностика діабету». 2. «Цілі опіки та підходи до лікування». 3. «Модифікація способу життя при діабеті». 4. «Фармакотерапія діабету». 5. «Комплексна допомога при діабеті». 6. «Роль фармацевта в навчанні та наданні підтримки самоменеджменту діабету».

- Фармацевтичне товариство Австралії (Pharmaceutical Society of Australia) пропонує курс «Практика діабету для фармацевтів» (Diabetes in practice for pharmacists) та серію спеціалізованих вебінарів [2].

Висновки. В розвинутих країнах світу ролі фармацевтів/провізорів швидко змінюються. Наприклад, у Великобританії для підтримки розвитку клінічної практики у фармації, трансформації професії фармацевт та розвитку у фармацевтів необхідних клінічних навичок було започатковано спеціальний Фонд інтеграції фармації (The Pharmacy Integration Fund, England). В той же час в Україні роль цих фахівців досі здебільшого обмежується відпуском ліків і керуванням аптеками 
(управління запасами, замовлення ліків, ведення обліку). Але фармацевти/провізори можуть надавати хворим на ЦД пацієнтам багато інших послуг, таких як управління медикаментозною терапією, узгодження призначення ліків та профілактика (скринінг, імунізація, просвіта та консультування з питань поведінки, харчування). У деяких країнах такі послуги надаються на базі аптек, що спеціалізуються на обслуговуванні хворих на ЦД та обстеженні людей із груп ризику. I хоча поки надання додаткових послуг залишається обмеженим i непослідовним, зростання кількості хворих на ЦД надалі буде стимулювати пошук економічно ефективних способів боротьби з ЦД. Цілком зрозуміло, що паралельно необхідно змінювати робочі процеси, розробляти нові моделі фармацевтичної практики, що можуть бути масштабовані, та надавати фармацевтам/провізорам інституційної та методичної підтримки.

Фармацевти/провізори ідеально підходять для надання ФО пацієнтам хворим на ЦД. Аналіз медичної статистики показує, що їх залучення до «управління хворобою» у відношенні ЦД (diabetes DSM):

1) покращує глікемічний контроль [11], затримує початок розвитку ускладнень ЦД;

2) $є$ економічно ефективним (більшість витрат на лікування ЦД пов'язані саме 3 ускладненнями захворювання, включаючи ампутації, сліпоту, кардіоваскулярні патології, інсульти та ниркові захворювання);

3) дозволяє надавати допомогу більшій кількості пацієнтів, охопити діабетичною освітою широкі верстви населення;

4) сприяє покращенню загальної якості життя людей [10], підвищенню задоволеності пацієнтів якістю свого життя [6].

В той же час, опанування нових ролей, в тому числі просвітницької, вимагає від фармацевтів/провізорів поглибленої спеціалізації, додаткового навчання та практики в обраному напрямку, а також суттєвого вдосконалення комунікативних навичок (наприклад, вміння навчати дорослих людей). Тож для організації підготовки фармацевтів/провізорів для лікування хворих на ЦД в рамках реформи системи охорони здоров'я в Україні потрібні додаткові програми післядипломного навчання. Досвід, що вже накопичили розвинуті країни буде в цьому дуже корисним.

\section{ЛІТЕРАТУРА}

1. Clinical Pharmacy Education, Practice \& Research. Ed. by D. Thomas. Elsevier; 1 edition, 2018. DOI https://doi.org/10.1016/C2017-0-01328-9

2. Diabetes in practice for pharmacists www.diabetesqualified.com.au/course/pharmacists. Diabetes Webinar Series www.diabetesqualified.com.au/course/diabetes-webinar-series.

3. IDF Diabetes Atlas, 9th edition, 2019 (https://diabetesatlas.org/en/resources).

4. Margaret A. Powers, Joan Bardsley, Marjorie Cypress, Paulina Duker, Martha M. Funnell, Amy Hess Fischl, Melinda D. Maryniuk, Linda Siminerio, and Eva Vivian. Diabetes Self-management Education and Support in Type 2 Diabetes: A Joint Position Statement of the American Diabetes Association, the American Association of Diabetes Educators, and the Academy of Nutrition and Dietetics. Clin Diabetes. 2016 Apr; 34(2): 70-80. doi: 10.2337/diaclin.34.2.70

5. Marie Smith, Pharmacists' Role in Improving Diabetes Medication Management. Journal of Diabetes Science and Technology Volume 3, Issue 1, January 2009 doi: 10.1177/193229680900300120 PMCID: PMC2769842 PMID: 20046662

6. Pousinho S, Morgado M, Falcao A, et al: Pharmacist interventions in the management of type 2 diabetes mellitus: a systematic review of randomized controlled trials. J Manag Care Spec Pharm 2016;22:493-515

7. Redesigning the health care team: Diabetes prevention and lifelong management. NIH Publication No. 117739 NDEP-37. Bethesda, MD: National Diabetes Education Program; Revised June 2011. Retrieved from https://www.chcact.org/resource-files/DIABETEsPREVENTIONLIFELONGMNGMNT.pdf

8. Team Care Approach for Diabetes Management. Working Together to Manage Diabetes: A guide for pharmacy, podiatry, optometry, and dentistry. Retrieved from www.cdc.gov/diabetes/ndep/pdfs/ppodguide-team-care-approach.pdf

9. The IDF School of Diabetes, IDF Certified Course for Diabetes Educators (www.idfdiabeteschool.org).

10. Wang Y., Yeo Q. Q., Ko Y., Economic evaluations of pharmacist-managed services in people with diabetes mellitus: a systematic review. Diabetic Medicine, Volume 33, Issue 4, April 2016, Pages 421-427 https://doi.org/10.1111/dme.12976.

11. Wubben D.P., Vivian E.M. Effects of pharmacist outpatient interventions on adults with diabetes mellitus: a systematic review. Pharmacotherapy. 2008 Apr;28(4):421-36. doi: 10.1592/phco.28.4.421. 